\title{
Confidentiality of the medical records of HIV-positive patients in the United Kingdom - a medicolegal and ethical perspective
}

This article was published in the following Dove Press journal:

Risk Management and Healthcare Policy

25 January 2011

Number of times this article has been viewed

\section{Mike Williams}

Head of Service, Cambridge University Dental Service,

Cambridge, UK
Correspondence: Mike Williams Head of Service, Cambridge University Dental Service, 3 Trumpington Street, Cambridge, CB2 IQA, UK Emailmhw39@cam.ac.uk
Abstract: This article examines the legal and ethical issues that surround the confidentiality of medical records, particularly in relation to patients who are HIV positive. It records some historical background of the HIV epidemic, and considers the relative risks of transmission of HIV from individual to individual. It explains the law as it pertains to confidentiality, and reports the professional guidance in these matters. It then considers how these relate to HIV-positive individuals in particular.

Keywords: HIV/AIDS, confidentiality, medical records

\section{Introduction}

In December 1981, an article appeared in the New England Journal of Medicine describing a curious cluster of just seven men who, for no apparent reason, had severe infections, previously associated only with profoundly immunologically compromised individuals. ${ }^{1}$ The mystery illness would soon enter common parlance as HIV and AIDS.

It is estimated that since the beginning of the epidemic, there have been 60 million people infected with HIV and 25 million HIV-related deaths. ${ }^{2}$

The introduction of highly active antiretroviral therapy (HAART) has led to a dramatic decline in morbidity and mortality among patients infected with HIV. ${ }^{3}$

The success of HAART has meant that in Britain and the North Western World, HIV/AIDS has been transformed from being a fatal disease to a chronic illness. ${ }^{4} \mathrm{Nev}-$ ertheless, HIV persists in infected individuals, who should be considered infectious for life. ${ }^{5}$ Ultimately, preventive vaccination will be the most efficient and cost-effective approach to stop the HIV epidemic. ${ }^{6}$ However, even optimistic estimates suggest a vaccine may not be available for a number of years, ${ }^{7}$ and even then may initially be only partially effective. ${ }^{8}$

In the United Kingdom, at the end of 2008, it was estimated that 83,000 people were living with HIV (1.3 people/1000 population). Over a quarter $(27 \%)$ were unaware of their infection. ${ }^{9}$ In 2008, 7298 new HIV cases were diagnosed; almost a third (32\%) was diagnosed late. ${ }^{9}$ Late diagnosis is associated with short-term mortality, ${ }^{10-12}$ implicated in onward transmission of infection, ${ }^{13,14}$ and is associated with increased care and management costs. ${ }^{15,16}$ Reasons for late presentation with HIV infection are complex and poorly understood, ${ }^{17}$ but include concerns about confidentiality. ${ }^{18,19}$

The relatively specific sexual connotations associated with HIV infection, and its association with drug addiction ${ }^{20}$ have meant that it is a highly stigmatized 
disease. ${ }^{21-23}$ AIDS-related stigma refers to the prejudice and discrimination directed at people living with AIDS, and can result in marginalization, discrimination, and even physical hurt. ${ }^{24} \mathrm{UN}$ Secretary-General, Ban Ki-moon has been quoted as saying, 'Stigma is a chief reason why the AIDS epidemic continues to devastate societies around the world' ${ }^{24}$

More bluntly, Arthur Schaffer describes HIV/AIDS as 'God's gift to bigots'. ${ }^{25}$ Inevitably then, individuals found to be HIV positive will have legitimate concerns about the confidentiality of their status. ${ }^{20}$

\section{Public health, professional guidelines, and the law}

Created in 2003, the remit of the Health Protection Agency (HPA $)^{26}$ is the anticipation, identification, and rapid response to infectious disease, threats, and other health dangers. Effective health protection for the community depends on early detection, rapid and effective intervention and control, and ongoing surveillance of the situation. An essential element of this is the categorization of diseases as 'notifiable'. ${ }^{26}$ A notifiable disease is one which a registered medical practitioner is legally bound to report to the relevant authorities, and failure to do so can result in summary conviction and fine. Notifiable diseases are defined in the Public Health (Control of Disease) Act 1984 for England and Wales ${ }^{27}$ and the Public Health (Infectious Diseases) Regulations $1988 .{ }^{28}$ The Secretary of State also has the powers to make such regulations as are required to respond to an immediate disease threat. ${ }^{29}$

HIV is not notifiable in the United Kingdom. Considering that infectious diseases such as hepatitis, mumps, and measles must be reported, the medical case for not making HIV notifiable does not exist. However, given the social stigma that has surrounded the disease, the concern has always been that patients would perceive a forced breach of their confidentiality as a threat to their interests and would not return for care or refuse to come forward, leaving health authorities with no effective means by which they could monitor the disease. ${ }^{30}$

There is a tension then between HIV/AIDS as a personal issue and a matter for the individual, and as a social issue with public interest concerns. ${ }^{31}$

It seems likely that McNair's man on the Clapham omnibus, the ordinary $\operatorname{man}^{32}$ would regard medical confidentiality as a straightforward matter, an expectation that details about a patient's medical condition, and treatment remains a secret between the patient and those that treat him. ${ }^{33}$ Confidentiality is seen as 'an essential requirement for the preservation of trust between patients and health professionals, ${ }^{34}$ an unequivocal concept, deeply ingrained in oaths and strict guidelines. ${ }^{35-37}$ General Medical Council (GMC) guidance makes it clear that patients have a right to expect that information about them will be held in confidence by their doctors. ${ }^{38}$ This is easily applied to a historic model, with each patient cared for largely by a single physician keeping relatively few notes, ${ }^{39}$ but more difficult in current modern medical practice, with patients likely to be treated by a large number of health care professionals. ${ }^{39,40}$ Clinical records are quite widely circulated among professionals, some of whom may be less deeply indoctrinated than their medical colleagues in matters of confidentiality. ${ }^{20,41}$ The inevitable increase in computer technology makes protecting confidentiality more complex, and this has led some to shift the focus to the notion of data protection. ${ }^{40}$

It is argued that in reality, individuals have never been literally in control of their medical records, and what is lost is the 'illusion' that patients maintained control of their personal information disclosed as part of a patient-physician relationship. ${ }^{42}$

Moreover, it is not difficult to envisage a scenario where information given in confidence to a doctor should be revealed. ${ }^{43}$ Indeed, the Hippocratic Oath has doctors swear to keep secret and never reveal that 'which ought not to be spread abroad,' with the implication that circumstances might exist where this should happen. ${ }^{39}$

Revealing a patient's confidential medical details might be said to be a breach of contract; this might be applied to private (non-National Health Service [NHS]) patients, but less easily applied to NHS patients where there is no contract with anyone caring for them. ${ }^{40} \mathrm{~A}$ breach of contract claim could also be raised if infringement of patient confidentiality was in effect a breach of the health care professional's contract of employment. ${ }^{44}$ This remedy, however, would be open only to the employer, unless a patient could make a claim under the Contracts (Rights of Third Parties) Act 1999. ${ }^{40}$

If a medical professional either revealed or failed to take adequate steps to ensure that others did not discover a patient's protected information, an action could be brought in tort for negligence. ${ }^{45}$ However, there may be only limited benefit for the claimant because tort damages are generally for financial or physical loss..$^{40}$

The patient could rely on the equitable obligation to respect confidential information. Four criteria must be satisfied:

1. The information must be personal, private, or intimate in nature. ${ }^{46,47}$

2. The information must be given in circumstances that impose an obligation of confidence. 
3. It may be necessary to show that an individual must actually suffer from the release of the information. This might allow the release of anonymized information. ${ }^{48}$ However, even if the revealed information does not harm a particular individual, it may be argued that a public harm arises (eg, distrust of doctors). ${ }^{49,50}$ Hence, it is accepted that even if a patient has died, details of his or her medical condition should not be made public. ${ }^{40}$

4. A breach of confidence requires only that an unauthorized person sees the information. It does not have to be made public. $^{51}$

A claim for breach of confidence could only be raised by the person to whom a duty of confidentiality is owed. ${ }^{52}$ Clearly, the person who breaches the duty may be sued; however, an action could also be raised against someone who comes into possession of information, and despite knowing or suspecting that it is confidential publishes it. ${ }^{46}$

Although it could be argued that a patient owns the medical information that relates to him or her as an individual, and might therefore bring a property claim, it is generally accepted that it is the NHS Trust that owns the records made by its staff. ${ }^{48}$ In criminal law, information is not property capable of being stolen, ${ }^{53}$ although the paper on which it is written could be. Were someone to hand over a medical record to a third party, they could be guilty of theft, not of the information but of the record itself. ${ }^{40}$

The Computer Misuse Act 1990 does criminalize unauthorized access to databases of confidential information. ${ }^{54}$ This means a health care professional would be guilty of an offence under the act if they were to access records to gather information about someone who was not in their professional care.

The European Convention on Human Rights article 8 protects the right to respect for private and family life, and also protects confidential information. This was a prominent feature in Campbell v MGN, ${ }^{47}$ the leading case in breach of confidence. Article 8 should be considered as central to the protection of confidentiality. ${ }^{40}$ As the European Court of Human Rights (ECHR) explained in Z v Finland. ${ }^{55}$

The protection of personal data, not least medical data, is of fundamental importance to a person's enjoyment of his or her right to respect for private and family life as guaranteed by article 8 of the convention. Without such protection those in need of medical assistance may be deterred from revealing such information of a personal and intimate nature as may be necessary in order to receive appropriate treatment, and even from seeking such assistance, thereby endangering their own health and, in the case of transmissible diseases, that of the community.
There have, however, been inconsistencies in the court's judgment, ${ }^{56}$ and these fundamental rights are not absolute. ${ }^{57}$ In Z v Finland, the Finnish State was found to be in breach of Z's privacy. The court stated that considerations of privacy were especially valid in the circumstances of Z's seropositivity. However, seizing Z's medical records and ordering her doctors to give evidence did not violate article 8 , because there were good reasons for requiring this information. Article 8 (2) gives public authorities a broad margin for justifying disclosure of medical information. Seizing Z's medical records was not disproportionate; however, revealing her identity and allowing the information to become public was a disproportionate interference with her right to respect for her family and private life. ${ }^{39}$

I v Finland ${ }^{58}$ involved a district authority that failed to establish a register from which a HIV-positive employee's confidential patient information could not be the subject of unauthorized disclosure. The court's view was that it is insufficient to simply have remedies of compensation for the injured parties, and retrospective sanctions against those who have accessed the records unlawfully. The court required an assurance that domestic legislation contains sufficient safeguards to exclude the possibility of any such unauthorized access occurring.

It has been suggested that NHS databases in the United Kingdom may not be able to meet such a high threshold of protection, given that it would involve restricting access, and the maintenance of an audit trail of those who have accessed the clinical records. ${ }^{59}$

A number of statutes impose obligations in matters of confidential information. The Data Protection Act 1998 is the most significant, but the National Health Service (Venereal Diseases) Regulations $1974^{60}$ and the Human Fertilisation and Embryology Act $1992^{61}$ were introduced to give statutory emphasis to the obligation of confidence in these areas of medical practice.

The National Health Service (Venereal Diseases) Regulations 1974 impose a statutory duty on a health authority to enforce a duty of confidentiality, by virtue of the common law (or statute) between the patient and doctor or health authority. ${ }^{62}$ The obligation of confidence under the regulations applies to sexually transmitted diseases. It has been suggested that patients, who are HIV positive following infection by some other means, may need to look to the common law for protection of their confidentiality. ${ }^{62}$ However, it can be argued that within the regulations, a sexually transmitted disease is a disease that is usually transmitted through sexual contact, but which may be transmitted by 
other means. ${ }^{62}$ On this analysis, HIV remains within the regulations irrespective of the means of infection, and this is argued by Rose $\mathrm{J}$ in $\mathrm{X} \vee \mathrm{Y}^{44}$

The Data Protection Act covers the processing of all personal data stored in systems whether paper based or electronic. Health records are classified as sensitive personal data under the act and are subject to special protection. ${ }^{63}$ If a person suffers damage or loss as a result of violation of the act, he or she could receive compensation. Other statutes create specific exceptions to the duty of confidentiality, requiring health professionals to disclose certain information, regardless of patient consent. ${ }^{64-70}$

In addition to the law, the various professional regulatory bodies issue guidelines on confidentiality. The GMC issued new guidelines on confidentiality in October 2009, ${ }^{71}$ and the British Medical Association (BMA) has published extensive information and guidance on confidentiality and the disclosure of health information. ${ }^{34} \mathrm{~A}$ wide range of other policies and standards exist, providing guidance in matters of confidentiality, including the Caldicott Guardian Manual (2006), the Department of Health (DoH) Confidentiality: NHS code of practice (2003), the Scottish Government Health Directorate NHS Code of Practice on Protecting Patient Confidentiality (2003), and the Northern Ireland Code of Practice on Protecting Confidentiality of Service User Information.

The NHS Care Record Guarantee emphasizes the commitment of the NHS to confidentiality and security of patient information.

\section{Exceptions to the rules}

The GMC guidelines remind doctors that though confidentiality is an important duty, it is not absolute. Personal information can be disclosed if 1) it is required by the law, 2) the patient consents, and 3) it is justified in the public interest. $^{71}$

A defense to alleged breach of confidentiality would be a threat of serious harm to others. Here, the public interest in protecting innocent people from harm outweighs the public interest in protecting confidentiality. ${ }^{40}$ This equitable notion, easily understood in principle, raises a number of questions. How serious must the harm be to others that would allow a breach of confidentiality; should an individual who poses a threat to others, perhaps through no fault of their own, be denied the protection of the law on confidence?

Another defense might be that the disclosure was justified in the public interest and to stimulate public debate. ${ }^{40}$ The BMA and GMC guidance is clear: to justify disclosure there must be a real risk of serious harm. When considering disclosing information to protect the public interest, doctors must:

- "Consider how the benefits of making the disclosure balance against the harms associated with breaching a patient's confidentiality both to the individual clinical relationship and to maintaining public trust in a confidential service.

- Assess the urgency of the need for disclosure.

- Persuade the patient to disclose voluntarily.

- Inform the patient before making the disclosure and seek his or her consent, unless to do so would enhance the risk of harm or inhibit effective investigation.

- Disclose the information promptly to the appropriate body.

- Reveal only the minimum information necessary to achieve the objective." 34

- Seek assurances that the information will be used only for the purpose for which it was disclosed and be able to justify the decision. ${ }^{34}$

Nonconsensual disclosure is generally only considered justifiable in cases where there is a threat to society or to an individual, of serious crime, or serious harm such as a serious communicable disease. ${ }^{71}$ Disclosure of personal information may be justified in the public interest, without the patient's consent, and in exceptional circumstances where patients have withheld consent, if the benefits to an individual or to society of the disclosure outweigh both the public and patient's interest in keeping the information confidential. ${ }^{71}$ Doctors are advised to seek consent to disclosure where practicable, and to inform the patient about disclosure even if they have not sought consent, unless it was impracticable to do so. ${ }^{71}$

\section{HIVIAIDS infection - the risks of transmission}

The proportion of babies that acquire HIV infection from untreated HIV-seropositive mothers is $15 \%-25 \%$ in developed countries, and $25 \%-45 \%$ in developing countries. $^{72}$ The frequency of HIV transmission attributable to breastfeeding is $16 \%{ }^{72}$ The risk of HIV transmission associated with orogenital sex exists, but is considered extremely low, ${ }^{72}$ although there are currently insufficient data to estimate the risk precisely. ${ }^{73}$ Studies of cumulative HIV incidence suggest that cofactors such as genital ulcer disease, HIV disease stage, and male circumcision influence HIV transmission. ${ }^{74}$ The heterosexual infectivity of HIV-1 is commonly cited as a fixed value: approximately 
0.001 or 1 transmission/1000 contacts. However, this figure was estimated among stable couples with low prevalence of high-risk factors, and represents a lower bound.$^{74}$ It has been suggested that estimates based on models assuming constant infectivity are likely to be misleading, underestimating the risk after very few contacts, and overestimating the risk associated with a large number of contacts. ${ }^{75}$ Unprotected anal intercourse in men who have sex with men is a high-risk practice for HIV transmission, ${ }^{76}$ but studies report a quite wide variation in seroconversion rates in different groups. ${ }^{77-79}$

People in the process of seroconverting may be much more infectious than asymptomatic infected people, ${ }^{80,81}$ and it is reported that primary- and late-stage HIV-1 infections are more infectious than previously thought. ${ }^{82}$ However, in a homogenous population, the asymptomatic stage of infection will typically contribute more to the net transmission of HIV-1 over the lifetime of an infected individual, because of its longer duration. ${ }^{82}$ Transmission from women to men appears less efficient than from men to women, as has been reported with other sexually transmitted diseases. ${ }^{83,84}$ Importantly, the consistent use of condoms has been shown to reduce HIV incidence by $80 \% .{ }^{85}$ However, it is recognized that HIV-positive individuals do not always inform their sexual partners of their serostatus, ${ }^{86,87}$ which may influence condom use.

It is important, when considering public health risk, to recognize that the virus does not pass from one person to another through ordinary day-to-day social contact. 88,89

\section{The HIV-positive patient}

A doctor, on diagnosing a patient with HIV should explain to the patient:

- How they can protect others from infection, including practical measures to avoid transmission of the virus.

- The importance of informing sexual contacts about the risk of transmission.

- That, unless they object, personal information about them will be shared within the health care team, including some nonclinical staff involved in their care. ${ }^{90}$

If the doctor is aware that a HIV-positive patient has not informed their sexual partner, it would be permissible for the doctor to alert that partner in order for them to take steps to avoid infection even if the patient refuses to consent to others being informed. ${ }^{39,40}$

“... you may disclose information to a known sexual contact of a patient with a sexually transmitted, serious communicable disease where you have reason to think that they are at risk of infection and that the patient has not informed them, and cannot be persuaded to do so. In such circumstances you should tell the patient before you make the disclosure, ... you must be prepared to justify a decision to disclose personal information without consent."90 "Information must not be disclosed to others eg, relatives who have not been and are not at risk of infection." ${ }^{34}$

The advice leaves the responsibility for action entirely with the individual doctor, ${ }^{30}$ and is couched in terms of it being permissible to tell others, rather than there being a duty to tell others. ${ }^{40}$ Partner disclosure is a very complex issue, because of the diversity of types of relationships and varying levels of intimacy, power, and trust. ${ }^{91}$ A recent study reports that GPs were more likely, given hypothetical scenarios, to inform partners when protection was not used during intercourse and when heterosexual rather than homosexual relationships were involved. The risk to the partner only partially explained the relationship between patient use of protection and decision making. Physician background and characteristics, and HIV patient sexual practice and orientation are also involved." 92

In United Kingdom law, no duty to warn exists in the absence of a special relationship between the parties, although a number of cases in non-United Kingdom jurisdictions suggest a common-law duty or statutory duty to inform those at risk. ${ }^{93-95}$ It is possible that in the United Kingdom, a doctor might be held to have a duty to warn a third party who was also his patient. Here, the relationship might be deemed sufficiently proximate to require positive action. ${ }^{30}$

The Human Rights Act places a duty on the state to protect the lives of citizens (Article 2) and protect them from inhuman or degrading treatment (Article 3), and also places a duty on the NHS to inform individuals at risk. ${ }^{40}$

In the United Kingdom, there has been no decision directly taken on this point. It is arguable that a patient would have a right of action against a doctor who informed a sexual partner of potential risk, as a prima facie breach of confidence. It seems likely that the court would balance the interests of those involved and hold the disclosure to be justified. The dilemma is that relaxation of the rule on confidentiality might lead to failure to seek advice and treatment, and hence promote the spread of disease, whereas unyielding confidentiality denies to some the opportunity to avoid the risk of exposure or, in the event of exposure, to seek early treatment. $^{30}$

It should be remembered that the Crown Prosecution Service (CPS) has successfully prosecuted a number of HIV-positive individuals following the transmission of 
HIV through unprotected, consensual intercourse to an unsuspecting partner, contrary to the recklessness provisions of section 20 of the Offences Against the Person Act 1861 (OAPA). ${ }^{96,97}$ Although the criminalization of HIV transmission has been criticized by some, ${ }^{98}$ it is clear that such prosecutions have been something of a priority for the $\mathrm{CPS}^{99}$

In 2008, the CPS issued guidelines to clarify the law. As of 2008, a person can only be convicted of reckless sexual HIV transmission if there is, '... a sustained course of conduct during which the defendant ignores current scientific advice regarding the use of safeguards'. While recognizing concerns about discrimination, the guidelines go on to say.

"We will be mindful of any indications that there is a disproportionate impact on any particular group of individuals that we may prosecute ... however, where there is sufficient evidence and it is in the public interest to prosecute, the CPS has a duty to the complainant and to society at large to bring the defendant before the courts ...."

Even supporters of the criminalization of HIV transmission agree that in the case of casual or commercial sex with strangers, the victim can be taken to have consented to the risks, and the victim's consent prevents criminal liability. ${ }^{101}$

The 1861 act has never extended to Scotland. However, common law in Scotland has consistently recognized all intentionally inflicted physical injury to be criminal. The scope of intention clearly is an issue. However, the first successful prosecution for actual transmission of HIV was brought about in Scotland. ${ }^{102}$

In Scotland, the possibility exists of prosecution for the inchoate offence of reckless endangerment. This means that it could be possible in principle to convict an individual of reckless endangerment simply for having intercourse in the knowledge that he or she might be HIV positive even if it turns out that he or she is not. ${ }^{103}$

\section{HIV-positive health care workers}

'Any departure from the strictest anonymity in respect of HIVrelated information must be subject to intense scrutiny' ${ }^{30}$ HIV-positive health care workers (HCW) have come under particular scrutiny. The low risk of transmission from $\mathrm{HCW}$ to patient is estimated variously as ranging from 1 in 42,000 to 1 in $1,000,000,{ }^{104}$ or unlikely to occur more frequently than once/1000 person-hours of surgical exposure. ${ }^{105}$ Scully and Porter in a review of the CDC studies ${ }^{106}$ concluded that HIV transmission from $\mathrm{HCW}$ to patient is exceedingly improbable and almost impossible where recommended infection-control procedures are implemented.
There has been no known case in the United Kingdom of HIV infection being transmitted from a HCW to a patient. ${ }^{107}$ Nevertheless, worldwide there have been three reports of transmission of HIV to patients from HCWs performing exposure-prone procedures (EPPs): a Florida dentist, ${ }^{108}$ a French orthopedic surgeon, ${ }^{109}$ and a Spanish obstetrician. ${ }^{110}$ The exact route of transmission in these cases has not been determined. ${ }^{107}$ There is also an unusual case that occurred in France, where a HIV-infected nurse transmitted the virus to a patient, where again no defined route of transmission has been determined. ${ }^{111}$ In addition, there has been one case of patient-to-patient transmission of HIV, where a Sydney surgeon, whose breaches of proper procedures led to the transmission of HIV from a HIV-positive male to four women who had visited the surgeon's rooms for minor surgery. ${ }^{112}$ The surgeon himself was not HIV positive.

The UK policy and guidance relating to HIV-infected HCWs is set out in a Department of Health (DoH) report. ${ }^{113}$

- Healthcare workers have legal and ethical duties to protect the health and safety of their patients. They also have a right to respect and protection of their confidentiality.

- In the majority of cases, HIV infected healthcare workers do not present a risk of transmission to patients in the healthcare setting; providing appropriate infection control measures are maintained.

- Circumstances in which HIV could be transmitted from a healthcare worker to a patient are limited to exposure prone procedures, which it goes on to define. Essentially, these arise where injury to the healthcare worker could result in the worker's blood contaminating the patient's open tissues (bleed-back). HIV infected healthcare worker must not perform any exposure prone procedures, which are defined in the report.

- HIV infected healthcare workers must seek advice and not rely on their own assessment of their risk to patients. ${ }^{113}$

The DoH guidance goes on to place a burden on professional colleagues, knowing of a HIV-infected individual practicing in a way which places patients at risk, to inform an appropriate person in the HCW's employing authority, or the relevant regulatory body, and this is reinforced in the GMC guidance..$^{90} \mathrm{~A}$ doctor then, while having a duty of confidentiality to the infected $\mathrm{HCW}$, would be required to disclose information in the public interest to protect others. ${ }^{114}$

For many HCWs, HIV seropositivity is not a barrier to normal working practice. ${ }^{113}$ For others, changes in working routine have been a prerequisite of being allowed to continue to work. ${ }^{115}$ These have included an obligation to have frequent 
health checks, a requirement for patients to sign a consent form stating that they knew that the HCW (a surgeon) was HIV positive, and the opportunity for patients to ask to be treated by another surgeon if they so wished. ${ }^{115}$ Some (eg, dentists) despite challenges to the scientific basis for the decision, ${ }^{116-118}$ are obliged to cease contemporary clinical practice. $^{119}$

The identification of HCWs with a positive-HIV diagnosis has led to multiple patient notification exercises (lookback procedures). ${ }^{113,120-122}$

With the exception of a French orthopedic surgeon, lookback procedures have conspicuously failed to identify any transmission of HIV from an infected HCW to a patient, ${ }^{123-125}$ but inevitably led to the identification of the HCW's HIV status to all patient contacts.

The low risk of transmission has called into question the value of look-back procedures, which are considered disruptive and expensive, and it is claimed that they should no longer be routinely recommended. ${ }^{121,126,127}$ Since 2003, DoH guidance has advised that look-back procedures take place in rare circumstances only. ${ }^{128}$ Nevertheless, others argue forcefully that look-back procedures are important, ${ }^{129}$ and they continue to be set in motion. ${ }^{130,131}$

The 2003, DoH guidance followed the case of H (a HCW) v Associated Newspapers Ltd. ${ }^{132}$ H's respect for private life ${ }^{133}$ was set against the right to freedom of expression of the press. ${ }^{134} \mathrm{H}$ also challenged the right of the health authority to undertake a look-back procedure.

In balancing the tension between articles 8 and 10 of the Human Rights Act, the appeal court held that there was a public interest in maintaining H's confidentiality, and upheld the injunction against naming $\mathrm{H}$ or $\mathrm{N}$ (the health authority). However, the risk of discovery of H's identity was insufficient to continue restriction on disclosure of his specialty (as a dentist), as this was deemed a matter of public interest worthy of debate.

Similarly, although the court was clear about the public interest in preserving the confidentiality of HIV-positive HCWs if they are not to be discouraged from coming forward, and that all possible steps should be taken to preserve their anonymity, it recognized that it may prove impossible to prevent identification of the worker. The court took the view that look-back procedures were a matter of patient safety and that the anonymity of the HCW may have to be sacrificed in the interest of patients.

The rationality of public and media response to the knowledge of HCWs diagnosed as HIV positive has varied. ${ }^{135}$ However, surveys have shown that patients do want to know if their doctor or dentist is infected with HIV, ${ }^{136,137}$ and this may be a factor in determining valid consent for treatment. ${ }^{138,139}$

The issues surrounding HIV-infected HCWs require actions based on "a realistic and scientifically accurate determination of the risk of infection, which do not needlessly violate the core political values that underwrite a free and democratic society." "140 The burden of proof should lie on those who seek to limit the rights of people with HIV. This is important if the rights of the HIV-positive minority in the community are not to be overturned because of the demands of an apprehensive majority. Currently, it would seem that the merest possibility of a risk is sufficient to justify what may otherwise be regarded as unequal and right-infringing treatment. ${ }^{140}$

In 1986, the Centers for Disease Control and Prevention stated that mandatory HIV screening of HCWs who performed invasive procedures was not necessary because testing would not further reduce the 'negligible risks of transmission'. ${ }^{141}$ The 2007 DoH guidance ${ }^{142}$ requires HCWs who are new to the NHS and carry out EPPs to have additional health clearance checks to demonstrate they are free from infection with hepatitis BV, hepatitis C, HIV, and Tuberculosis. Medical and dental students are also required to undergo additional health clearance before being accepted onto their course. The new guidelines have been criticized, ${ }^{143}$ and it has been argued that in effect mandatory HIV testing has now been introduced for a large number of HCWs. ${ }^{144}$

Appropriate information sharing is essential to the efficient provision of safe, effective care for individual and the wider community of patients. ${ }^{71}$

If a patient refuses to allow information to be passed to someone outside the health care team of their infection status, their wishes must be respected, unless it is felt that failure to disclose the information will put other HCWs or other patients at risk.

The risk of transmission from patient to $\mathrm{HCW}$ is low, with a seroconversion rate of $0.1 \%$ after percutaneous exposure, and $0.63 \%$ after mucous membrane contamination, and the use of universal procedures should be enough to protect HCWs from infection, thereby making disclosure unnecessary to prevent serious harm. ${ }^{145}$ Notwithstanding this, there have been a number of recorded occupational infections. ${ }^{146}$ The combined risk of contracting HIV infection from the source patient and then transmitting it to another during an EPP is so low as to be considered negligible, and HCWs are not required to refrain from performing EPPs pending follow-up of occupational exposure to a HIV-infected source. ${ }^{113}$ 
Prisons represent a high-risk environment for HIV transmission, ${ }^{147}$ as those engaging in high-risk behavior are disproportionately represented in the prison system. ${ }^{148}$ The prison service does have confidentiality policies that are largely convention-compliant; however, local application of these policies can be inconsistent and there are common breaches of confidentiality.

The Health and Social Care Act 2001 allows the disclosure of medical information for research purposes without a patient's consent, if it is necessary or expedient in the interests of improving patient care, or in the public interest.

The GMC guidance acknowledges that in most cases it will be possible to engage patient consent or to use anonymized or coded data, but goes on to provide guidance should this not be possible. ${ }^{71}$ The BMA advises a cautious approach, unless the health professional is confident that they can make a reasonable assessment as to whether or not the research is in the public interest. ${ }^{34}$ The training of medical staff, clinical research, and medical audit require access to patient information. It has been suggested that the emphasis on confidentiality is an interference with research. ${ }^{149}$

It can be argued that the use of medical records in an epidemiological study, with no intention to disclose patient identity, reduces the public interest in maintaining secrecy in favor of the public interest in health care provision. ${ }^{39}$ In R v Department of Health ex parte Source Informatics Ltd, ${ }^{150}$ the Court of Appeal's view was that the general public would not object to their medical information being used if it was anonymized. The decision takes no account of the fact that a patient's information might be used in a way that indirectly harms them, particularly so in an already vulnerable group. The decision has been criticized as virtually abolishing the duty of confidence in the face of competing commercial and research interests. ${ }^{151}$ In fact, it has been shown that public acceptability regarding the use of medical records cannot be assumed. ${ }^{152}$ It has been argued that a more important aspect of the decision in Source Informatics is to move the focus away from the protection of confidential information to fairness of use, a shift away from protection of patients' privacy to an attention on the conscience of the user. ${ }^{40}$

GMC guidelines are clear that the duty of confidentiality continues after a patient has died. ${ }^{71}$ This is an ethical and moral duty; it is thought that legal duty of confidentiality expires with the patient. ${ }^{39}$ The cause of death, as written on a death certificate, in effect, becomes public knowledge.

\section{Discussion}

Patients value their right to confidentiality, ${ }^{153}$ and are reported to have high levels of confidence in the way the NHS protects their confidentiality. ${ }^{154}$ However, they may have limited knowledge of the type of information held in their records, ${ }^{155}$ and are not always well informed about how the information is used. ${ }^{154}$ Patients have clear opinions about who should have access to their records, with a substantial minority wishing to restrict it, ${ }^{156}$ having particular unease about information being passed to people outside the NHS. ${ }^{154}$

The introduction of a national electronic health record system has raised issues about security and confidentiality. Unsurprisingly, patients are keen to censor information that relates to sensitive or embarrassing issues, which may affect the way a patient may be treated by other individuals or institutions, being shared on the national electronic database. ${ }^{157}$ English Law does not recognize a general right of privacy. ${ }^{158}$ Courts have been willing to protect the identity of HIV-positive individuals, ${ }^{159}$ but sometimes confine their decision to very narrow grounds. ${ }^{160}$

"HIV infection is a very personal issue and a matter for the individual, but it is also a public and social issue." ${ }^{\prime 31}$ The effectiveness of public health measures in checking the epidemic must be weighed against the sacrifices those measures demand of individual citizens. ${ }^{140}$ It has been stated that the law is at best limited in its ability to tackle the AIDS threat. ${ }^{31}$ Medically and legally, HIV/AIDS appears to be less of a widespread problem in the United Kingdom than in much of the world, ${ }^{161}$ and it seems that for a variety of reasons, people living in Britain with HIV/AIDS do not litigate. Consequently, legislation that may assist them remains underused. ${ }^{162}$

Reasons why people do not litigate are complex, but appear to be related to publicity generated by litigation, and the low levels of compensation for unlawful treatment. ${ }^{161}$ It has also been reported that people with HIV/AIDS are reluctant to take legal advice even when they feel they have suffered discrimination. ${ }^{163}$

It is argued that the central weakness of HIV/AIDS law in the United Kingdom stems from the fact that litigants and their advisers readily settle out of court, and thus the law remains underdeveloped. ${ }^{161}$

Even among the general population, few cases are brought in matters of confidentiality. Two remedies would be available to a claimant: an injunction to prevent publication, and the award of damages. An injunction would of necessity require advance notice of disclosure of the information. More usually, the patient would only become aware of the disclosure after 
the event, and the court would still need to be convinced that there was no public interest element.

Since the Human Rights Act, courts have robustly protected the individual's rights to confidentiality of health data. ${ }^{165,166}$ Confidentiality of health data is seen as a vital principle in the legal system, crucial not only to respect the sense of privacy of a patient, but to preserve confidence in the medical profession and in health services in general. ${ }^{58}$

Campbell v MGN establishes the right to protection of private information in English Common Law, and identifies three tests:

1. '... reasonable expectation test'

2. '... highly offensive to a reasonable person of ordinary sensibilities test'

3. '... obviously private' 59

HIV-positive patients might justifiably have a reasonable expectation that their medical records remain confidential.

Finally, no discussion of HIV/AIDS can fail to recognize that in general, HIV is increasingly a disease of poverty, ${ }^{166}$ with a disproportionate impact on racial and ethnic minorities. ${ }^{167}$ Many in this already disadvantaged and stigmatized group will be least able to protect their rights of confidentiality.

\section{Conclusion}

Confidentiality is a fundamental principle, grounded in the patient's right to autonomy, and enabling the patient to have an open and honest dialogue with his or her medical professional, with benefits to the individual and the general public health.

For most individuals, the main cause for concern is likely to be the casual social disclosure of their HIV status. Although there may be a whole raft of legislation, ultimately, there will still be a heavy reliance on the moral and ethical standards of the medical profession.

\section{Disclosure}

The author reports no conflicts of interest in this work.

\section{References}

1. Robert S. Aids in historical perspective. In: Michael G, editor. Dental Management of Patients with HIV. Chicago, IL: Quintessence Publishing Co, Inc; 1994:11.

2. UNAIDS. Global facts and figures. Available from: http://www.unaids. org/en/pub/FactSheet/2009/20091124-FS. Accessed June 2010.

3. Yazdanpanah Y, Sisoko D, Egger M, Mouton Y, Zwahlen M, Chene G. Clinical efficacy of antiretroviral combination therapy based on protease inhibitors or non-nucleoside analogue reverse transcriptase inhibitors: indirect comparison of controlled trials. BMJ. 2004;328:249.

4. Jocelyn Elder's foreword to Webber DW. AIDS and the Law. New York, NY: Aspen; 1997. As reported in: Watt B, editor. HIV/AIDS and European Human Rights Law. Bob Watt European Human Rights Law Review. 2000.
5. Levy JA. HIV and the Pathogenesis of AIDS. Washington, DC: ASM Press; 1994:17.

6. Graham B. Clinical review. Science, medicine, and the future. Infection with HIV-1. BMJ. 1998;317:1297-1301.

7. Will there be an HIV vaccine in the next 10 years? Nat Med. 2007;13: 518-519.

8. Day M. AIDS expert doubts vaccine will be found in near future. $B M J$. 2007;334:1133.

9. Health Protection Agency. HIV in the United Kingdom: 2009 Report. Available from: www.hpa.org.uk. Accessed June 2010.

10. Sabin C, Smith C, Youle M, et al. Deaths in the era of HAART: contribution of late presentation, treatment exposure, resistance and abnormal laboratory markers. AIDS. 2005;20:67-71.

11. Chadborn T, Baster K, Delpech V, et al. No time to wait: how many HIV-infected homosexual men are diagnosed late and consequently die? (England and Wales, 1993-2002). AIDS. 2005;19:513-520.

12. Chadborn TR, Delpech VC, Sabin CA, Sinka K, Evans BG. The late diagnosis and consequent short-term mortality of HIV-infected heterosexuals (England and Wales, 2000-2004). AIDS. 2006;20(18): 2371-2379.

13. NIMH Multisite HIV prevention Trial. Reducing HIV sexual risk behavior. Science. 1998;280:1889-1894.

14. Kamb ML, Fishbein M, Douglas JM Jr, et al. Efficacy of risk-reduction counselling to prevent human immunodeficiency virus and sexually transmitted diseases: a randomized controlled trial. Project RESPECT Study Group. JAMA. 1998;280:1161-1167.

15. Krentz H, Auld M, Gill M. The high cost of medical care for patients who present late $(\mathrm{CD} 4<200$ cells/microL) with HIV infection. HIV Med. 2004;5:93-98.

16. Yazdanpanah Y, Goldie S, Losina E, et al. Lifetime cost of HIV care in France during the era of highly active antiretroviral therapy. Antivir Ther. 2002; 7:257-266.

17. Suzanne Crowe, Jennifer Hoy, John Mills, eds. Management of the HIV-Infected Patient. Cambridge, MA: Cambridge University Press; 1996.

18. Burns F, Mercer CH, Mercy D, Sadiq ST, Curran B, Kell P. Factors that may increase HIV testing uptake in those who decline to test. Sex Transm Infect. 2004;80:249.

19. Speilberg F, Bransom BM, Goldbaum GM, et al. Overcoming barriers to HIV testing: preferences for new strategies among clients of a needle exchange, a sexually transmited disease clinic, and sex venues for men who have sex with men. J Acquir Immune Defic Syndr. 2003; 32:318-327.

20. Mason JK, Laurie Mason GT. Medical confidentiality. In: Mason and McCall Smith's Law and Medical Ethics. 7th ed. Oxford, UK: Oxford University Press; 2006.

21. Grov C, Golub SA, Parsons JT, Brennan M, Karpiak SE. Loneliness and HIV-related stigma explain depression among older HIV-positive adults. AIDS Care. 2010; Apr 16. [Epub ahead of print]

22. Wagner AC, Hart TA, Mohammed S, Ivanova E, Wong J, Loutfy MR. Correlates of HIV stigma in HIV-positive women. Arch Womens Ment Health. 2010;13(3):207-214.

23. Valdiseri R. HIV/AIDS stigma: an impediment to public health. Am J Public Health. 2002;92(3):341-342.

24. HIV and AIDS discrimination and stigma. Available from: http://www. avert.org

25. Arthur Schafer. AIDS: the social dimension. In: Overall C, Zion WP, editors. Perspectives on AIDS. Ethical and Social Issues. Oxford UK: Oxford University Press; 1991:3.

26. Her Majesty's Stationery Office. Health Protection Agency Act 2004 London, UK: The National Archives; 2004.

27. Her Majesty's Stationery Office. Public Health (Control of Disease) Act 1984s10. London, UK: The National Archives; 1984.

28. Her Majesty's Stationery Office. Public Health (Infectious Diseases) Regulations 1988 SI 1988/1546. London, UK: The National Archives; 1998.

29. Her Majesty's Stationery Office. Public Health (Control of Disease) Act 1984s13. London, UK: The National Archives; 1984. 
30. Mason JK, Laurie GT. Ch 2 Public health and the state/patient relationship. In: Mason and McCall Smith's, Law and Medical Ethics. 7th ed. Oxford, UK: Oxford University Press; 2006.

31. Brenda Almond. Personal issues and personal dilemmas. In: Brenda Almond, editor. AIDS: A Moral Issue. The Ethical, Legal and Social Aspects. Basingstoke, UK: McMillan Press Ltd; 1990.

32. Her Majesty's Stationery Office. Bolam v Friern Hospital Management Committee. [1957] 2 All ER 118 at 121, [1957] 1 WLR 582 at 586.

33. Her Majesty's Stationery Office Ashworth Security Hospital v MGN Ltd [2000] 1 WLR 515 Lord Phillips MR at 527. London, UK: The National Archives; 1984.

34. British Medical Association. Confidentiality and disclosure of health information tool kit. BMA guidance. Available from: http://www.bma. org.uk/ethics. Accessed Dec 2009.

35. The Hippocratic Oath. Available from: http://www.patient.co.uk/doctor/ Ideals-and-the-Hippocratic-Oath.htm. Accessed June 2010.

36. The Declaration of Geneva. 1948. Adopted by the General Assembly of World MEdical Association at Geneva, Switzerland, September 1948. (revised June 6, 2002). Available from http://www.cirp.org/library/ ethics/geneva. Accessed June 2010.

37. World Medical Association. WMA International Code of Medical Ethics. Ferney-Voltaire, France: WMA; 1949.

38. General Medical Council. Confidentiality. Guidelines for Doctors. October 2009. Available from: http://www.gmc.org. Accessed June 2010.

39. Confidentiality. In: Jackson E, editor. In: Medical Law: Text, Cases and Materials. Oxford, UK: Oxford University Press; 2006.

40. Herring J. Medical Law and Ethics. Oxford, UK: Oxford University Press; 2008.

41. Sheikh A. Confidentiality and privacy of patient information and records: a need for vigilance in accessing, storing and discussing patient information. MLJI. 2010;16:2.

42. Parker L. Information (al) matters: bioethics and the boundaries of the public and private (2002) 19 social philosophy and policy 83-112, 89-90. In: Jackson E, editor. As reported in Medical Law: Text, Cases and Materials. Oxford, UK: Oxford University Press; 2006:317.

43. Her Majesty's Stationery Office W v Edgell [1990] 1 All ER 835. London, UK: The National Archives; 1990.

44. Her Majesty's Stationery Office X v Y [1988] 2 All ER 649. London, UK: The National Archives; 1988.

45. Her Majesty's Stationery Office Swinney v Chief Constable of Northumbria Police [1996] 3 All ER 449. London, UK: The National Archives; 1996.

46. Her Majesty's Stationery Office Stephens v Avery [1988] 2 All ER 477. London, UK: The National Archives; 1988.

47. Her Majesty's Stationery Office Campbell v MGN [2004] UKHL 22. London, UK: The National Archives; 2004.

48. Her Majesty's Stationery Office R v Department of Health ex p Source of Information Ltd. [2000] 1 All ER 786. London, UK: The National Archives; 2000.

49. Her Majesty's Stationery Office Stone v South East Strategic Health Authority [2006] EWHC 1668 (Admin). London, UK: The National Archives; 2006.

50. Her Majesty's Stationery Office Ashworth v MGN [2001] 1 All ER 191. London, UK: The National Archives; 2001.

51. Her Majesty's Stationery Office A-G v Guardian (No 2) [1990]1 AC 109, 260. London, UK: The National Archives; 1990.

52. Her Majesty's Stationery Office Fraser v Evans (1969) 1 All ER 8. London, UK: The National Archives; 1969.

53. Her Majesty's Stationery Office Oxford v Moss (1978) 68 Cr App R 183. 1978

54. Her Majesty's Stationery Office R v Bow Street Metropolitan Stipendiary Magistrate ex p Government of the USA [2000] 2 AC 216.

55. Z v Finland (1998) 25 EHRR 371 paras 95-96.

56. Colak v Germany (77144/01): HIV-patient confidentiality as reported in European Human Rights Law Review. 2009.
57. ECJ as reported in The legal protection of HIV+ve healthcare workers and the human rights jurisprudence of the European Court of Justice. Bob Watt European Human Rights Law Review 1998. [1992] ECRI-2575.

58. I v Finland (2009)48 EHRR.

59. Moreham NA. Privacy in the common law: a doctrinal and theoretical analysis. Law Q Rev. 2005.

60. Her Majesty's Stationery Office SI 1974 No 29.

61. Her Majesty's Stationery Office Human Fertilisation and Embryology Act 1990 as amended by the Human Fertilisation and Embryology (Disclosure of Information) Act 1992. London, UK: The National Archives; 1992.

62. Medical Law: Ch 8. Kennedy, Grubb. Oxford, UK: Oxford University Press; 2005.

63. Her Majesty's Stationery Office Data Protection Act 1998 Schs 1 and 3. London, UK: The National Archives; 1998.

64. Her Majesty's Stationery Office The Public Health (Control of Diseases) Act 1984. London, UK: The National Archives; 1984

65. Her Majesty's Stationery Office Public Health (Infectious Diseases) Regulations 1988. London, UK: The National Archives; 1988.

66. Her Majesty's Stationery Office. Abortion Regulations 1991. London, UK: The National Archives; 1984.

67. Her Majesty's Stationery Office. Reporting of Injuries, Diseases and Dangerous Occurrences 1995. London, UK: The National Archives; 1984.

68. Her Majesty's Stationery Office. Road Traffic Act 1988. London, UK: The National Archives; 1984.

69. Her Majesty's Stationery Office. Terrorism Act 2000. London, UK: The National Archives; 1984.

70. Her Majesty's Stationery Office. Information Sharing Index (England) Regulations 2007. London, UK: The National Archives; 1984.

71. General Medical Council. Confidentiality. Guidelines for doctors. Oct 2009. Available from: http://www.gmc.org/. Accessed June 2010.

72. McCarthy GM, Ssali CS, Bednarsh H, Jorge J, Wangran K, Page-Shafer K. Transmission of HIV in the dental clinic and elsewhere. Oral Dis. 2002;8 Suppl 2:126-135.

73. Baggaly RF, White RG, Boily MC. Systematic review of orogenital HIV-1 transmission probabilities. Int J Epidemiol. 2008;37: 125-165.

74. Powers KA, Poole C, Cohen MS. Rethinking the hetrosexual infectivity of HIV-1: a systematic review and meta-analysis. Lancet Infect Dis. 2008;9:553-563.

75. Downs AM, De Vincenzi I. Probability of heterosexual transmission of HIV: relationship to the number of unprotected sexual contacts. European Study Group in Heterosexual Transmission of HIV. J Acquir Immune Defic Syndr Hum Retrovirol. 1996;11(4):388-395.

76. Baggaley RF, White RG, Boily MC. HIV transmission risk through anal intercourse: a systematic review, meta-analysis and implications for HIV prevention. Int J Epidemiol. 2010;39(4):1048-1063.

77. Yang H, Hao C, Huan X, et al. HIV incidence and associated factors in a cohort of men who have sex with men in Nanjing China. Sex Transm Dis. 2010 Feb 23 [Epub ahead of print]

78. van der Snoek EM, de Wit JB, Götz HM, Mulder PG, Neumann MH, van der Meijden WI. Incidence of sexually transmitted diseases and HIV infection in men who have sex with men related to knowledge, perceived susceptibility, and perceived severity of sexually transmitted diseases and HIV infection: Dutch MSM-Cohort Study. Sex Transm Dis. 2006;33(3):193-198.

79. Lavoie E, Alary M, Remiss RS, et al. Determinants of HIV seroconversion among men who have sex with men living in a low HIV incidence population in the era of highly active antiretroviral therapies. Sex Transm Dis. 2008;35(1):25-29.

80. Leynaert B, Downs AM, Vincenzi I. Heterosexual transmission of human immunodeficiency virus: variability of infectivity throughout the course of infection. European Study Group on Heterosexual transmission of HIV. Am J Epidemiol. 1998;148:88-96. 
81. Wawer MJ, Gray RH, Sewankambo NK, et al. Rates of HIV-1 Transmission per Coital Act, by stage of HIV-1 infection in Rakai, Uganda. J Infect Dis. 2005;191(9):403-409.

82. Hollingsworth TD, Anderson RM, Fraser C. HIV-1 transmission by stage of infection. J Infect Dis. 2008;198(5):687-693.

83. Johnson AM, Laga M. Heterosexual transmission of HIV. AIDS. 1988; 2 Suppl 1:S49-S56

84. Nicolosi A, Corrêa Leite ML, Musicco M, Arici C, Gavazzeni G, Lazzarin A. The efficiency of male-to-female and female-to-male sexual transmission of the human immuno-deficiency virus: a study of 730 stable couples. Italian Study Group on HIV Heterosexual Transmission. Epidemiology. 1994;5(6):570-575.

85. Weller S, Davis K. Condom effectiveness in reducing heterosexual HIV transmission. Cochrane Database Syst Rev. 2001;3:CD003255.

86. Wong LH, Rooyen HV, Modiba P, et al. Test and tell: correlates and consequences of testing and disclosure of HIV status in South Africa (HPTN 043 Project Accept). J Acquire Immune Defic Synd. 2009;50(2): 215-222.

87. Sullivan KM. Male self-disclosure of HIV-positive serostatus to sex partners: a review of the literature. J Assoc Nurses AIDS Care. 2005; 16(6):33-47.

88. AVERT HIV transmission. Frequently asked questions. AIDS and HIV information. Available from: http://www.avert.org. Accessed June 2010.

89. Centers for Disease Control and Prevention. HIV transmission. Questions and answers CDC HIV/AIDS. Available from: http:/www.cdc. gov/hiv/resources/qa/index.htm. Accessed June 2010.

90. General Medical Council. Confidentiality: disclosing information about serious communicable diseases. Supplementary guidance. Available from: http://www.gmc.org/. Accessed June 2010.

91. Lohman D, Amon JJ. HIV testing and human rights. Lancet. 2008; 371(9612):557-558.

92. Daly M, Hevey D, Regan C. The role of perceived risk in general practitioners' decisions to inform partners of HIV-infected patients. Br J Health Psychol. 2010; May 5 [Epub ahead of print].

93. Tarasoff $\mathrm{v}$ Regents of the University of California 529 P2d 55 (Cal 1974); on appeal 551 P2d 334 (Cal 1976).

94. PD v Harvey and Chen [2003] NSWSC 487.

95. Reisner v Regents of the University of California 37 Cal Rptr 2d 518 (1995).

96. R v Dica [2004] 3 WLR 213, [2004] 3 All ER 593.

97. R v Konzani [2007] CFLQ 112 1st Mar.

98. Cameron E. Criminalization of HIV transmission: poor public health policy. HIV AIDS Policy Law Review. 2009 Dec;14(2):1 63-75.

99. Grievous Harm? Use of the Offences against the Person Act 1861 for sexual transmission of HIV. Briefing paper. Catherine Dodds, Peter Weatherburn, Ford Hickson, Peter Keogh, Will Nutland. P 2.

100. The Crown Prosecution Service. Policy for prosecuting cases involving the intentional or reckless sexual transmission of infection. 2008 Available from: http://www.cps.gov.uk/publications/prosecution/sti. html. Accessed June 2010.

101. Weait M. Taking the blame: Criminal law. social responsibility and sexual transmission of HIV. J Soc Welf Fam Law. 2001;23(4):441-457.

102. HMA v Kelly unreported. 2001. High Court of Justiciary, Glasgow, 23 February. In: Mason JK, Laurie GT. Mason and McCall Smith's, Law and Medical Ethics. 7th ed. Oxford, UK: Oxford University Press; 2006:341.

103. Warburton D. A critical review of English law in respect of criminalising blameworthy behaviour by HIV+ individuals. J Crim Law. 2004;68(55):1194-1215.

104. Rhames FS. The HIV-infected surgeon. JAMA. 1990;264:507-508; Bell DM, Martone WJ, Culver DH, Margolis HS, Shapiro C, et al. Risk of endemic HIV and hepatitis B virus (HBV0 transmission to patients during invasive procedures abstract). In Abstracts from the VII International Conference on AIDS; 1991 Jun, vol I:16-21.
105. Rogers AS, Froggatt JW, Townsend T, et al. Investigation of potential HIV transmission to the patients of an HIV infected surgeon. JAMA. 1993;269(14):1795-1801.

106. Scully C, Porter S. Can HIV be transmitted from dental personnel to patients by dentistry? BDJ. 1993;175(10):381-382.

107. Health Protection Agency. United Kingdom Advisory Panel for healthcare workers infected with bloodborne viruses. Annual Report 2003 Apr 1 to 2004 Mar 31. Available from: http://www.hpa.org.uk/web/ HPAwebFile/HPAweb_C/1194947413302. Accessed June 2010. p. 9.

108. Ciesielski CA, Marianos DW, Schochetman G, White JJ, Jaffe HW. The 1990 Florida dental investigation. The press and the science. Ann Intern Med. 1994;121(11):886-888.

109. Lot F, Séguier JC, Fégueux S, et al. Probable transmission of HIV from an orthopaedic surgeon to a patient in France. Ann Intern Med. 1999;130(1):1-6.

110. Mallolas J, Arnedo M, Pumarola T, et al. Transmision of HIV-1 from an obstetrician to a patient during a caesarean section. AIDS. 2006;20(2):285-287.

111. Astagneau P, Lot F, Bouvet E, et al. Lookback investigation of patients potentially exposed to HIV type 1 after a nurse-to-patient transmission. Am J Infect Control. 2002;30:242-245.

112. Zinn C. Sydney surgeon accused of HIV transfer. BMJ. 1994;309: 1603.

113. Department of Health. HIV-infected health care workers: Guidance on management and patient notification. Department of Health Annual Report August 2005 (replacing 1998 version). Available from: http:// www.dh.gov/uk/publications. Accessed June 2010.

114. Medical Law: Ch 8. Kennedy, Grubb. Oxford: Oxford University Press; 3rd ed. 2005.

115. Christie B. HIV positive surgeon allowed to operate. BMJ. 1996;313:1279.

116. Centers for Disease Control and Prevention. Investigation of patients treated by and HIV-infected cardiothoracic surgeon - Israel 2007. MMWR Morb Mortal Wkly Rep. 2009;57:1413-1415.

117. Vernazza P, Hirschel B, Bernasconi E, Flepp M. Les personnes séropositives ne souffrant d'aucune autre MST et suivant un traitment antirétroviral efficace ne transmettent pas le VIH par voie sexuelle. Bull Med Suisses. 2008;89:165-169.

118. Oral Health and Disease in AIDS Beijing Declaration 2009. The Mouth and AIDS. The Global Challenge. The 6th World Workshop on Oral Health and Diseases in AIDS. Apr 21-24, 2009, Beijing, The People's Republic of China.

119. Health Protection Agency. UK Advisory Panel for healthcare workers infected with blood-borne viruses (UKAP) Available from: http:// www.hpa.org.uk/web/HPAweb\&Page\&HPAwebAutoListName/ Page/1203496960618. Accessed June 2010.

120. Robert LM, Chamberland ME, Cleveland JL, et al. Investigations of patients of health care workers infected with HIV: The Centres for Disease Control and Prevention Database. Ann Intern Med. 1995; 122(9):653-657.

121. Irwin DJ, Millership S. Description of an HIV patient notification exercise in Essex involving a dental healthcare worker. Commun Dis Public Health. 2002;5(4):276-281.

122. Scully C, Greenspan JS. Human immunodeficiency virus (HIV) in dentistry. J Dent Res. 2006;85(9):794-800.

123. Von Reyn CF, Gilbert TT, Shaw FE, Parsonnet KC, Abramson JE, Smith MG. Absence of HIV transmission from an infected orthopaedic surgeon. A 13-year look-back study. JAMA. 1993;269(14): 1807-1811.

124. Dickinson GM, Morhart RE, Klimas NG, Bandea CI, Laracuente JM, Bisno AL. Absence of HIV transmission from an infected dentist to his patients. An epidemiologic and DNA sequence analysis. JAMA. 1993;269(14):1802-1806.

125. Jaffe HW, McCurdy JM, Kalish ML, et al. Lack of HIV transmission in the practice of a dentist with AIDS. Ann Intern Med. 1994; 121(11):855-859. 
126. Donnelly M, Duckworth G, Nelson S, et al. Are HIV lookbacks worthwhile? Outcome of an exercise to notify patients treated by an HIV infected health care worker. Incident Management Teams. Commun Dis Public Health. 1999;2(2):126-129.

127. Mason BW, Cartwright J, Sandham S, Witeside C, Salmon R. A patient notification exercise following infection control failures in dental surgery. Br Dent J. 2008;205(4):E8.

128. Department of Health. AIDS/HIV infected health care workers: guidance on the management of infected health care workers and patient notification - a consultation paper 2002. Available from: http://www. dh.gov.uk/en/Publicationsandstatistics/Publications/PublicationsPolicyAndGuidance/DH_4006650. Accessed June 2010.

129. Jagger J, Perry JL. Response to Mallolas et al. Obstetrician-to-patient HIV transmission (correspondence). AIDS. 2006;20(13):1785-1786.

130. BBC. Yorkshire hospital patients face tests in HIV scare. 2010. http:// news.bbc.co.uk/1/hi/england/10377839.stm. Accessed 2010 Jun 22.

131. BBC. HIV test patients in Yorkshire face 'low risk'. 2010. Available from: http://news.bbc.co.uk/1/hi/england/10388917.stm. Accessed 2010 Jun 23

132. H (A Healthcare Worker) v Associated Newspapers Ltd; H (A Healthcare Worker) v N (A Health Authority) [2002] EWCA Civ 195.

133. Human Rights Act 1988 Article 8.

134. Human Rights Act 1988 Article 10.

135. Pell J, Gruer L, Christie P, Goldberg D, Management of HIV infected health care workers: lessons from three cases. BMJ. 1996;312: 1150-1152.

136. Tuboku-Metzger J, Chiarello L, Sinkowitz-Cochran RL, CasanoDickerson A, Cardo D. Public attitudes and opinions toward physicians and dentists infected with bloodborne viruses: results of a national survey. Am J Infect Control. 2005;33(5):299-303.

137. Blatchford O, O'Brien SJ, Blatchford M, Taylor A. Infectious healthcare workers: should patients be told? J Med Ethics. 2000;26(1):27-33.

138. Rogers v Whittacker (1992) 109 ACLR 625 at 631. [1993] at 4 Med LR 79 at 82 .

139. Mason JK, Laurie GT, editors. Mason and McCall Smith's Law and Medical Ethics. 7th ed. Oxford, UK: Oxford University Press; 2006:407.

140. Bickenbach JE. AIDS and disability. In: Overall C, Zion WP, editors. Perspectives on AIDS. Ethical and Social Issues. Oxford, UK: Oxford University Press; 1991:13-14.

141. Recommendations for preventing transmission of human immunodeficiency virus and hepatitis B virus to patients during exposure-prone invasive procedures. Centers for Disease Control. Bull Am Coll Surg. 1991;76(9):29-37.

142. Department of Health. Health clearance for tuberculosis, hepatitis B, hepatitis C and HIV: new healthcare workers. 2007. Available from: http://www.dh.gov.uk/en/Publicationsandstatistics/Publications/ PublicationsPolicyAndGuidance/DH_073132. Accessed June 2010.

143. Salkeld LR, McGeehan SJ, Chaudhuri E, Kerslake IM. HIV testing of junior doctors: exploring their experiences, perspectives and accounts. J Med Ethics. 2009;35(7):402-406.

144. Salkeld L, McGeehan S. HIV testing of health care workers in England - a flawed policy. J Health Serv Res Policy. 2010;15 Suppl 2:62-67.

145. Ippolito G, Puro V, de Carli G.The risk of occupational human immunodeficiency virus infection in healthcare workers. Italian Multicentre Study. The Italian Study Group on Occupational Risk of HIV Infection. Arch Intern Med. 1993;153:1451-1458.

Risk Management and Healthcare Policy

\section{Publish your work in this journal}

Risk Management and Healthcare Policy is an international, peerreviewed, open access journal focusing on all aspects of public health, policy, and preventative measures to promote good health and improve morbidity and mortality in the population. The journal welcomes submitted papers covering original research, basic science, clinical \& epidemio-
146. Scully C, JS Greenspan CDC 2002. As reported in human immunodeficiency virus (HIV) transmission in dentistry. J Dent Res. 2006;85(9):794-800.

147. Jürgens R, Ball A, Verster A. Interventions to reduce HIV transmission related to injecting drug use in prison. Lancet Infect Dis. 2009;9(1):57-66.

148. Arnott H. HIV/AIDS, prisons and the Human Rights Act. Eur Hum Rights Law Rev. 2001;1:71-77.

149. Patterson (2001), Al Shahi R, Warlow C (2000) In: Herring J. Medical Law and Ethics. Oxford, UK: Oxford University Press;2008:233.

150. R v Department of Health ex p Source Informatics Ltd [2000] 1 All ER 786 (2001) QB 424 (CA).

151. Beyleveld D, Histed E. Betrayal of confidence in the court of appeal. Med Law Int. 2000;4(3-4):277-311.

152. Robling MR, Hood K, Houston H, Pill R, Fay J, Evans HM. Public attitudes toward the use of primary care patient record data in medical research without consent: a qualitative study. J Med Ethics. 2004;30(1): 104-109.

153. Benson J, Britten N. Respecting the autonomy of cancer patients when talking with their families: qualitative analysis of semi-structured interviews with patients. BMJ. 1996;313:729-731.

154. National Health Service Information Authority (2002).

155. Stone MA, Redsell SA, Ling JT, Hay AD. Sharing patient data: competing demands of privacy, trust and research in primary care. $\mathrm{Br} J$ Gen Pract. 2005;55(519):783-789.

156. Bolton Research Group. Patients' knowledge and expectations of confidentiality in primary health care: a quantitive study. $\mathrm{Br} \mathrm{J}$ Gen Prac. 2000;50(460):901-902.

157. Powell J, Fitton R, Fitton C. Sharing electronic health records: the patient view. Inform Prim Care. 2006;14(1):55-71.

158. Her Majesty's Stationery Office. Kaye v Robertson [1991] F.S.R. 62. London, UK: The National Archives; 1991.

159. Her Majesty's Stationery Office. X v Y [1988] 2 All E.R. 648. London, UK: The National Archives; 1988.

160. Re D unreported, CO/3369/97 1997 Nov 17, as reported in; the legal protection of HIV positive healthcare workers and the human rights jurisprudence of the European Court of Justice. Bob Watt European Human Rights Law Review. 1998:62.

161. HIV/AIDS and European Human Rights Law. Bob Watt European Human Rights Law Review. 2000:54.

162. Webley L. HIV/AIDS discrimination: why are there so few cases? Litigator. 1997:232-235.

163. Her Majesty's Stationery Office. The Lawyer 1999 Jun 30 Avrom Sherr. London, UK: The National Archives;1999.

164. Her Majesty's Stationery Office. A v X (Disclosure: Non-party Medical Records [2004] EWHC 447. London, UK: The National Archives; 2004.

165. Her Majesty's Stationery Office. A London Borough Council V Mr. and Mrs. N (foster carers of the child) (1), P (A child by her guardian Pauline Bennett) [2005] EHWC 1676. London, UK: The National Archives; 2005.

166. Smith Fawzi MC, Jagannathan P, Cabral J, et al. Limitations in knowledge of HIV transmission among HIV-positive patients accessing case management services in a resource-poor setting. AIDS Care. 2006; 18(7):764-771.

167. Cargill VA, Stone VE. HIV/AIDS: a minority issue. Med Clin North Am. 2005;89(4):895-912.

\section{Dovepress}

logical studies, reviews and evaluations, guidelines, expert opinion and commentary, case reports and extended reports. The manuscript management system is completely online and includes a very quick and fair peer-review system, which is all easy to use. Visit http://www.dovepress. com/testimonials.php to read real quotes from published authors. 